\title{
9 The role of Pentecostalism in sustainable development in Nigeria
}

\author{
Mobolaji Oyebisi Ajibade
}

\section{Introduction}

The role occupied by the Pentecostal Churches in Nigeria for development cannot be underestimated. ${ }^{1}$ Gaiya (2015) identifies two responses to social challenges by Charismatic Pentecostal Churches in Nigeria. One, he opines that churches taking a centripetal position are either socially passive or they collude with corrupt leaders and groups who undermine efforts towards political, social and human improvement; yet, in their engagement with society they offer spiritual solutions to myriad social and political problems. Two, he shows that churches taking a centrifugal approach try to confront political and social problems, but these churches are relatively few and located primarily in Lagos, although they are growing in influence. He concludes that charismatic Pentecostalism in Nigeria is shifting from strictly spiritual solutions for sociopolitical problems to an emphasis on meeting social needs in practical ways. Further to the observation of Gaiya above, in this work we observe the centrifugal aspect of Pentecostalism in Nigeria. This portends that our main concern is the role of Pentecostalism in sustainable development.

Certain works exist on the role of Pentecostalism in national development. For example, research has been carried out on a comparative analysis of social network in Yorùbá Culture and Nigerian Pentecostalism: Evidence from the Christ Way Church (CWC), Nigeria (Ajibade 2006); Christ Way Church and Politics of Cultural Identity (Ajibade 2010); A Study of Pentecostal Spirituality in Christian Home Video Films in Southwestern Nigeria (Ajibade 2013); the Role of Pentecostal Churches in Curbing Social Ills in Ife Central Local Government, Osun State (Ajibade 2014); and Filmic Construction of Pentecostal's Roles in Sustainable Democracy (Ajibade 2016). In these previous works, it is crystal clear that the roles of Pentecostal Churches in social networks and how Pentecostal spirituality is contributing to the well-being of their members cannot be underestimated. The current chapter, however, is in furtherance of research into the role of Pentecostal Churches in sustainable development in Nigeria, mainly in the south-west.

The methodology adopted is the historical survey research design and descriptive analytical approach employing oral interviews and questionnaires as 


\section{Mobolaji Oyebisi Ajibade}

tools for eliciting information. Specifically, the study involved the triangulation process, which consists of the field investigative method, interviews and content analysis. Oral interviews were conducted with nine purposively selected church leaders, three each from Redeemed Christian Church of God (RCCG), Ile-Ife; Winners Chapel, Ile-Ife and Christ Way Ministries International, Ile-Ife between 2016 and 2017. The RCCG was chosen to represent another brand of African Pentecostal Churches that stemmed from the Aladura movement. The Winners' Chapel (also known as Living Faith Church) represents another brand of Pentecostalism in Nigeria with prosperity and healing as their main emphasis. This church represents the urban Pentecostal Churches in south-western Nigeria. In other words, they represent urban-driven and rural-driven Pentecostal Churches. Christ Way Ministries International was chosen due to its ruraldriven attributes as a Pentecostal movement. In addition, questionnaires were administered to 45 members, 15 from each church. The research questions focus on information concerning Pentecostal's roles in sustainable development, the roles of the church leaders in sociopolitical matters, socioeconomic issues and on family and marriage issues that are topical in sustainable development of the society.

\section{Pentecostalism and the gospel of prosperity}

Truly, money is indispensable and vitally important for organic existence entailing the growth process. There is even a witty saying that, 'God made man, man made money, money made man'. That is an age-long saying that articulates the negative influence of crass materialism on the sublime values of humanity. Significantly, this saying holds true in the secular world as it does in the religious community comprised by churches, mosques, temples and shrines among others, where values would ordinarily be expected to be dominantly influenced spiritually. Critics have argued that the modern wave of Pentecostalism in Nigeria is so grossly materialistic in form and content that only a very thin line of distinction is left between churches and business enterprises (Corten and Marshall-Fratani 2001; Ukah 2006).

These new-wave Pentecostals put forward the idea that God wants believers to get rich. They preach, in essence, a gospel of Christian consumer capitalism. For the common worshipper, the promise of financial prosperity through a direct relationship with Jesus is a major pull factor, while membership of a church opens access to social and business networks within the church community. Hope of wealth and of positive change is what Pentecostal and Charismatic Churches offer their followers. In many instances, the Pentecostals make references to John the Apostle, who wrote, 'Beloved, I pray that you may prosper in all things and be in health, just as your souls prosper' (3 John: 2) and 'the Lord takes pleasure in the prosperity of his servant' (Psalm 35:27). They maintain that poverty-stricken people are not good ambassadors of the gospel. This kind of teaching shapes and transforms the philosophy and mentality of the congregants and the struggle to make the teachings work in their lives. Martin 
Lindhardt $(2010,258)$ opines that the Pentecostals have specialised in a preaching style that 'contributes to the production of a sophisticated, successful, urbanist image with a cosmopolitan fervor'. Nigerian Pentecostalism is a dynamic movement, with subtle changes of emphasis, beliefs and strategies. Within the modern Nigerian Pentecostal movement, there is an ongoing broadening of emphasis - from just saving souls to saving the society; from signs and wonders in the church, to service and influence in the society (McCain 2013, 160). Most of their teachings are appealing to the masses, especially those who have been battered by poor economy and bad governance. The churches have embraced secular values although they express them in religious language. They have succeeded in incorporating essentially secular elements, giving them a religious garb (Togarasei 2015, 65). Their impact on preaching morality cannot be underestimated either; Miller and Yamamori $(2007,33)$ posit that the 'incremental impact on people's social welfare' due to the social uplift associated with Pentecostalism's moral prescriptions against alcohol, gambling and womanising gives them a 'competitive economic advantage over their neighbours'.

In other words, the perception of Pentecostals in Africa about prosperity is that prosperity comprises spiritual, mental and physical areas of life. The underlying principle of their teachings and practices in regard to prosperity is that God will reward faithful Christians with good health, financial success and material wealth 'according to his glorious riches in Christ Jesus' (Philippians 4:19). Although some scholars opine that teachings of prosperity among the African Pentecostals take its root from America, Ojo $(1995,106)$ holds an opposing view that, 'the prosperity message is original to African Pentecostal churches'. The message of prosperity among the African Pentecostals also reflects their belief that the 'blessings of Abraham' have been willed to believers as beneficiaries of the new covenant through their acceptance of Christ Jesus as their Lord and Saviour (Galatians 3). The 'blessing of Abraham' is thus interpreted by the Pentecostals to include success in life's endeavours such as social, economic, political, religious and physical well-being. Corten and MarshallFratani $(2001,1)$ say, "believers no longer retreat among themselves in order to maintain the purity of their beliefs and their moral rigor. Their understanding of salvation is highly existential focusing on God's ability to deliver the believer from material things of this life'. This shapes the mentality of their members and eventually spurs them into actions of taking steps that will improve their condition of living.

The gospel of prosperity is believed to offer a doctrine of morally controlled materialism, in which personal wealth and success is interpreted as the evidence of God's blessing on those who lead a 'true' life in Christ. Many Pentecostals believe that prosperity gospel is probably an answer to the situation. The prosperity preachers believed that poverty is a sign of sickness that must be wiped out of the society. The vogue in the teachings of the majority of these churches is based on prosperity teaching. Positive confession is encouraged and sowing of seed of faith is the hallmark of such churches. Besides teaching of faith on prosperity, there are many programmes organised by many among the Pentecostals 


\section{Mobolaji Oyebisi Ajibade}

to educate their followers on how to make money. Workshops are organised where certain handiworks are taught to the applicants. This is very common in Living Faith Ministries, the RCCG, Deeper Christian Life Ministries, Christ Way Ministries International among others. These could be regarded as capacity building and empowerment programmes.

It must be pointed out, however, that another characteristic of the new Pentecostalism is the advent of truly anointed clergymen and women, who opted for flamboyant lifestyles to prove the point of the compatibility of godliness and prosperity. It is not that such lifestyles detracted from the divine unction and authenticity of God's calling upon their lives. Such revered spiritual leaders proved the point of compatibility with their lives and ministry. Late Archbishop Benson Idahosa, founder of the Church of God Mission International headquarters in Benin, Edo State, was an example of such a leader. It has even been remarked that the late clergyman was widely reputed as having been among the greatest proponents of the holiness doctrine and fiery evangelism of the world. Nevertheless, he was so materially endowed that his complete worth each time he stood to minister was estimated to be among the choicest and costliest that money could buy. It is indeed on record that he literally redefined pastoral ministry in Nigeria by breaking new grounds of service and rewards, including pioneering private Christian university ownership. As a mark of divine unction upon his life, his ministry was accompanied with miracles, signs and wonders. His ministry happened to be an example of Pentecostal Churches that has positively affected the masses.

Besides Idahosa, the majority of Pentecostal Churches in Nigeria today are investing in education. Many Pentecostal Churches have nurseries, primary and secondary schools and private universities. Although the idea is being criticised as too expensive and beyond the reach of the common man, even for the members of the churches who own these schools, these institutions no doubt have given many Nigerian applicants the opportunity of accomplishing their life dream of attending university in Nigeria. Also, many Nigerians are provided desired education and employment opportunities through these institutions. It is observed that there is an uninterrupted academic calendar in such schools as we have with most of the federal and state-owned universities. Christian moral principles are emphasised in these schools as well. The manpower being provided contributes in no small way to the nation's sustainable development in the political, social, religious and economic spheres (Omotoye 2010). As earlier said, education is one of the pillars and thrusts of sustainable development in any nation; then this is a commendable act on the part of Pentecostal movements in the nation.

Many of the Pentecostal Church founders are the 'alpha and omega' of such churches. They are worshipped like gods with bodyguards and are difficult to be seen by the members of the church. Following the radically laissez-faire stance that the new Pentecostal movement has assumed, there has been an obvious shift of the doctrinal emphasis from 'holy living' to earthly mastery of the prosperity gospel. Most programmes by many Pentecostal Churches and messages from their pulpits are now designed to teach the prosperity principle, without as 
much as teaching the stewardship principle by which prosperity can be channelled strictly to divinely ordained purposes. In this regard, it is difficult to exempt any type of Pentecostal or Charismatic Church, especially in this milieu. This, however, appears to have bred fortune hunters in the church, whose spiritual goal terminates at applying the prosperity doctrine to make their millions, without much concern for how to make heaven (that is, eternal rest that is assumed to be in a place called heaven or paradise) while making the millions. In effect, critics insist, much of the rat races in the secular world have rubbed off on the church. Indeed, if a census were to be taken, perhaps as high as three quarters of the programmes and messages in most of the new-wave churches are inspirational and material prosperity oriented (Ukah 2006). The prevailing culture of affluence seems to be putting some church members under pressure to also meet certain standards of wealth. This could be regarded as a negative influence of Pentecostals' praxis among the people. Benjamin and Nkechinyere $(2014,319)$ maintain that the pursuit of material prosperity appears to be the greatest factor that contributes to the promotion of Pentecostalism today, especially in Nigeria. Many who throng to Pentecostal Churches are people looking for prosperity, and being conscious of this fact, many of their ministers have turned prosperity preachers.

It must also be pointed out that unbridled emphasis on miracle ministrations is to the detriment of discipleship orientation of the adherents. The consequence of this is that many professing born-again Christians are in reality not disciples in the Christian lifestyle but are merely sign-seekers with ephemeral commitment to the faith they profess (Omotoye Williams 2010). However, this is not to deny the fact that faith healings and signs and wonders have their own space in sustainable development, most especially in a country where the political leaders including the president and his cabinet members go abroad for treatment of their illnesses - because they can afford it with government money. The beggar of the poor populace might not have a choice other than resigning to faith healing. Consequentially, we can assert that Pentecostals occupy an indelible space in giving hope to the hopeless in the society. This was even attested to by John Magbadelo $(2004,15)$, who wrote that:

The expansion of the reach of Pentecostalism was facilitated by the economic and political crises of the 1980s, which naturally and psychologically created adherents who were drawn from the pool of frustrated and marginalised people in the larger Nigerian society. The claim to 'power' by Pentecostal outreaches across the country was attested to by the numerous reports of instant miracles and wonder turnarounds experienced by several attendees, devotees and testifiers.

Miller and Yamamori $(2007,33)$ posit that the 'incremental impact on people's social welfare' due to the social uplift associated with Pentecostalism's moral prescriptions against alcohol, gambling and womanising gives them a 'competitive economic advantage over their neighbours'. 
In addition, many of the Pentecostal Churches in Nigeria built their own hospitals and clinics where they not only attend to their members but to other patients who seek healing. Providing health therapies to the people is one of the roles of the Pentecostals in sustainable development in the nation. Many Pentecostal Churches such as RCCG, the Living Faith (aka Winner Chapel), Deeper Christian Life Bible Church and many more provide employment opportunities to people through the establishment of banks, printing presses and lots more (Omotoye Williams 2010).

\section{Pentecostalism, marriage and family issues}

To Pentecostal Christians, social questions are essentially spiritual issues. The thriving story of Pentecostal Churches confirms their attitude to the institution of marriage and family issues.

It is the contention of the Pentecostal Christians that the curses on the land can be combated and removed only by fervent charismatic prayers, worship and exorcism, usually led by a faithful pastor. Pentecostals argue that all current problems stem from what they call demonic practices; anyone who has participated in traditional rituals is seen as someone who has been contaminated by demons and needs deliverance as depicted in many of the Christian home videos. Through their teachings, the Pentecostals teach that happy marriage is possible, and that divorce is not a good thing to do. It has been observed that the majority of the Pentecostal Churches we studied in southwestern Nigeria take the issue of blissful marriage as a serious matter. For example, Christ Way Ministries International, which has its headquarters in Ile-Ife, has designated every third Sunday as a family Sunday. In all their churches, on this third Sunday, the sermon and Bible studies must focus on family issues. They allow contributions from members of the congregation. It is like a workshop where the pastor or the invited pastor will just give a short message on a particular area relating to family. After the sermon, the members will have the opportunity to contribute to the debate. This has been the practice in this ministry for more than a decade. They usually have testimony along this line that most of them have stable and happy families. This is one of the factors that attract people who want a happy home to join this church.

The Pentecostals view marriage as a social and spiritual phenomenon. This is in tandem with David Maxwell's studies of Pentecostal Churches in Zimbabwe in the book entitled African Gifts of the Spirit (2006). Maxwell discusses ways in which Pentecostal movements influence husbands to be oriented to improving the lives of their wives and children and thereby uplifting their lives and the society at large in the process. The Pentecostals see marriage as a spiritual matter as well and they preach deliverance from the power of sin, forgiveness and restitution among others, which are considered as hindrances to a happy and stable family.

The Pentecostals maintain in their teachings that the ideal matrimonial love between man and woman is realised in monogamy and they equally sermonise against divorce. It has been duly observed that based on their teachings on 
marriage many Pentecostals have more stable families and homes than the nonmembers (Ajibade 2006, 2010 and 2013). In Nigeria, especially among the Yorùbá of the south-west, the issue of childbearing is taken seriously while everything is done to oppose barrenness. Importance placed on childbearing in many instances is one of what make Pentecostals attractive to women especially those who are looking to God for childbearing. Belief and faith in God's word that, 'With God nothing shall be impossible' (Luke 1:37) is helping many women to rely on God for provision of children for them. However, many critics of Pentecostal Churches opine that it is a trick. In fact, these critics maintain that one of the most attractive marketing tricks being employed by Pentecostal Churches nowadays is a promise of children to the barren. They opine that Pentecostals are taking advantage of the gullible state of the barren using posters, radio and TV to target this group of people. Many observers accuse the Pentecostal Churches of playing on the desperation of the women to lure them into the church. On the other hand, there are many women who have testified and are still testifying that they have received miracle babies.

\section{Pentecostalism and sociopolitical criticism}

As African Pentecostalism grows in popularity, a critical engagement with its social and political consequences is unavoidable. In Nigeria, Pentecostals are beginning to participate actively in civil society, embracing forms of political participation and social action they had formerly rejected. The activity of Pentecostals in social and political issues in the nation is becoming more apparent at the moment. They are involved in prayers for the nation and all sorts of political debates in diverse forms. This is concomitant with Ayuk $(2002,197)$ that

The Pentecostals are vigorously involved with the political life of Nigeria. They pray for the country and are involved in some government activities. Their preaching is not devoid of political innuendoes and a call for appropriate actions to be taken... Nigerians generally believe that it is God that has intervened in the changes that have taken place in the country politically. They think that God has answered their prayers. God has therefore acted in a political situation.

The rapid multiplication of new religious groups with charismatic tendencies cannot be explained merely by a favourable social environment. The Pentecostal groups also generate social change, albeit indirectly, exerting their influence from within the social structure and the political ideologies. Currently, the Christian Association of Nigeria, which is the overall umbrella for all Christians in Nigeria, is clamouring for the restructuring of Nigeria. It was reported by Friday Olokor (2018) that:

A coalition of elderly Christians under the aegis of the Christian Social Movement of Nigeria has said that towards moving Nigeria forward from its 
stagnant position, the restructuring of the country should be the major focus of the 2019 elections. The conference insisted that the foundation of Nigeria needed redressing in the form of a restructuring of the country, which should be a major agenda of the 2019 elections.

In contemporary Nigeria, Pentecostals have achieved a new level of maturity based on their activities and preaching on civil rights, political and social engagements. Increasingly, they desire to become the subjects of their own history and are casting their lot with the new forces that are emerging in the societies. Whenever social chaos reigns, there is room for religious explosions of the Pentecostal group. Their religious principles have a direct effect on poverty and economic behaviour, and they lend religious and ideological legitimacy to new motivations, activities and institutions. It is obvious in the Nigerian society that the Pentecostals are sensitising their members to the need to be politically aware in order to be well positioned to influence the way things are done in national politics and governance. This goes beyond the former regular practice of praying for the government. Likewise, the establishment of the Justice, Peace and Development Commission (JDPC) and National Christians Elders Forum (NCEF) for instance was one way the church thought it could mobilise its membership to play a more assertive role in the way the people are governed. They encourage and support their members to take active roles in polity at all levels. Members are encouraged to register in parties and to also enrol for voting by obtaining voters' cards.

It is not in doubt, therefore, that there has been tremendous improvement in the quality of governance the people get since the JDPC was established. At least, the politicians are conscious of the enormous powers the church wields. From my observation, it is cheering to note that in the past 15 years, the church has been in the vanguard of the agitation for the establishment of good governance, rule of law, constitutionality, social justice and equality in the country. For example, at the end of the National Christian Elders Forum of 18 June 2018 the following were the resolutions of the Body:

a Christians must speak with one voice and have one common agenda for 2019 Elections and subsequent years.

b The Church should agree on Christian Political Leadership. A body should be recognized to provide direction and harmonize all the various Christian resources into one formidable asset for Christianity to pursue the entrenchment of Democracy as the indisputable National Ideology of Nigeria. This body shall coordinate screening political parties as well as Christian political candidates. Without proper Christian Political Leadership, harmonization and coordination would be impossible. A house that is divided cannot stand.

c Promote the doctrines of Truth, Righteousness and Repentance in all Christian assemblies because 'righteousness exalts a nation but sin is a reproach to any people'. 
d The Church should be in vanguard of demand for a New Constitution to replace the one in use that has Sharia inclined military decrees grafted into it. There is need for proper understanding of the nature of Sharia by non-Islamist Nigerians in order to keep Nigeria Sharia free.

e Discard Sharia compliant Finance and Banking Acts (this includes Islamic Banking and SUKKUK).

f The Church should also demand the establishment a Truth and Reconciliation Commission as the basis for healing, reconciliation and forgiveness in the country.

g Establish a Law Review Commission to isolate Sharia in our statute books.

Supports CAN Trust Fund to mobilize critical funding to make Christianity in Nigeria financially independent.

(NCEF 2018)

The above came up as a result of the feelings of Christians that they are seriously marginalised in Nigeria.

Also, the setting up of the Christian Association of Nigeria (CAN) was borne out of exigency, geared towards protecting the integrity of the Christian religion in the nation's complex sociopolitical life. The Pentecostals strive to act as the conscience of the nation by watching over the politicians who have manipulated the gullibility of the electorates for their own self-aggrandisement. The church is embarking and fighting for the emergence of a more just and equitable society, where corruption will be banished, human rights promoted and peace and tranquillity well established.

The Pentecostals are even agitating that some of their members should take up political appointments to avoid being governed by corrupt politicians who have no good intentions and plan for the nation. Due to the Christians' view of being marginalised they are even regarded as the most critical of government policies and ideologies that are regarded as inimical to their existence in the nation (Olokor 2018). It is not only Christian groups that are rising up against different forms of social injustice in Nigeria; the overwhelming upsurge of militant and resistant groups in Nigeria these days such as the Niger Delta Militancy, OPC, Bakassi vigilantes, the Boko Haram episode and other similar movements are commonly interpreted as demonstrations against the state resulting from the strains of injustice in the system and as signalling the level of discontent among the citizenry (Uchegbue 2013, 142).

In order to participate actively in governance and embark on the process of sociopolitical and economic liberation for the realisation of justice, the church is expected to be seen as both a religious and viable social institution. Christians are to take positive actions to destroy all forms of oppressions and injustice wherever they are found (Hastings 1976, 91). But this is not to say that the church as a body should be expected to leave the word of God to serve tables by getting itself involved in a violent revolutionary overthrowing of 
governments or even in partisan political activism. The liberating role of the church should be such that will enhance its influence on the sociopolitical and economic order without jeopardising its more spiritual and evangelistic vision and mission. This will involve it confronting and challenging every unjust, oppressive and exploitative structure with Christian values and ideals (Uchegbue 2013, 149). However, this must be done without involving violence and violation of fundamental human rights.

\section{Sharing and caring in Pentecostalism}

In many Pentecostal Churches where there exists a social network, whenever any member is in a terrible social and economic mess, his/her Pentecostal group becomes his/her succour. They will not only give financial assistance to the person but will also organise intercessory prayers to support the family. This is a way of showing that when the political authority fails in any given state like that of Nigeria, the Pentecostal groups identify with their group members. Christian ethics also go a long way in helping Christians to cultivate sustainable lifestyles. This is in tandem with the Yorùbá indigenous social networking of caring for the needy in various dimensions.

Many Pentecostal Churches have established philanthropic organisations to help widows, the fatherless, orphans and the less-privileged people in the community. It is the contention of the Pentecostals that they should get involved in the social and political issues in their various communities and that they should choose to become active players in civil society and politics. It is within the civil society - that is, participating at the grass roots - that Pentecostalism will make a key contribution to deciding the prospect of the nation's social system not only through their teachings but also through their involvement in the welfare of their members. In other words, active involvement in the newly emerging civil society is a historic opportunity that must not be wasted. The transforming power of Pentecostalism resides not only in the coherence of its doctrine, but in its flexibility and its capacity to give expression to new social practices in the defining moments of a society in transition.

This practice and ideas of institutionalised giving by establishing a common purse for money and material things to be given to those that are in need is supported by the life of the early Christians (Acts, 2:44-46) where it was said:

All the believers were together and had everything in common. Selling their possessions and goods, they gave to anyone as he had need.... They broke bread in their homes and ate together with glad and sincere hearts.

For example, a committee of five is usually chosen to control the 'basket' in many Christ Way Churches. Any member of the church who is in need could approach any of the members of the committee. When the need of a particular person goes beyond the capacity of the purse of the welfare committee, then the case will be transferred to the pastor of the local assembly. In this period of 
economic recession (mainly from 2012 to date), especially in a situation when many states of the federation cannot pay the salaries of their workers for many months, the Pentecostals play prominent roles in serving as succour for the people in this category. Most of the Pentecostal Churches distribute food items to those who are in need, especially their church members. Even if all Christians in a community cannot be in a single place, the idea of giving support to their members who are in need is a practice that enhances their sustainability.

The Yorùbá people believe that one needs to exhibit the virtue of liberality and generosity in order to be vital in life. The Yorùbá people are hospitable; you don't need a formal invitation before you can visit somebody among them. To them, spiritual and material blessings accompany a liberal person and a giver never lacks as s/he continues to have abundance as encapsulated in the axiom, 'Òkè ni ọwọ́ afúnni ńgbé' - the hand of a giver is always on the top. Being on the top in this context means that such a giver will always prosper. It is the belief of the Yorùbá that the Supreme God watches over the people and he knows the givers and he is the only one that can pay them back by sending help to them in diverse ways. At the same time what one does for somebody today could be remembered by the recipient who would in turn pay it back in the future. Hence the saying, 'Oore loore ń wọ́ lé - one good turn deserves another. It is also a possibility for giving to take the dimension of commensalism and complementarities. The above is the principle of interrelation and interdependency among the Yorùbá. It means that whatever one lacks the other person might have, and concerted efforts benefit the community people. Their belief is that, 'Lánihuntán kan kil niwo esin' - no person in the world possesses everything needed for vitality'. Hence, seeing the practice of giving moral, material and financial support to those who are in need could be seen as a way through which the Pentecostals in Yorubaland are deploying the Yorùbá principle of caring and sharing.

\section{Conclusion}

Pentecostalism has grown in Nigeria because of its cultural fit into certain indigenous worldviews and its response to the questions that are raised within the interior of the worldviews. It asserts that the indigenous worldview still dominates the contemporary African experience and shapes the character of African Pentecostalism. Pentecostalism becomes a solace from the harsh realities of the collapse of economies, prowling poverty, lapses of the state, and failed leadership. It has been observed that various social networks established by the Pentecostal Churches in southwestern Nigeria enhance meeting various needs of their members.

It is observed that many Pentecostals have contributed and are still contributing significantly to the needed religious, political and socioeconomic infrastructure for the sustainable development of Nigeria in the twenty-first century. Mention must be made that regardless of the important role that the Pentecostals are playing in the sustainability of the country there is a lot of criticism against them. However, the Pentecostal Churches have contributed to 
sustainable development in the following areas: humanitarian services, educational development, employment provision, spiritual and moral development, and social and ethical development.

\section{Note}

1 Ayegboyin and Ishola $(1997,16)$ classify Pentecostalism as 'a general term used to describe the groups and sects which have traditionally placed emphasis on the speaking and receiving of certain gifts of the Spirit, such as, speaking in tongues, prophesying and healing as a sign of the baptism of the Holy Spirit'.

\section{References}

Ajibade, Mobolaji Oyebisi. 2006. 'A Comparative Analysis of Social Network in Yoruba Culture and Nigerian Pentecostalism: Evidence from the Christ Way Church (CWC), Nigeria.' M.A. diss., Universität Bayreuth.

Ajibade, Mobolaji Oyebisi. 2010. 'Christ Way Church and Politics of Cultural Identity.' Ife Journal of Religions 6, no. 1: 20-41.

Ajibade, Mobolaji Oyebisi. 2013. 'A Study of Pentecostal Spirituality in Christian Home Video Films in South-Western Nigeria.' Ph.D. diss., Obafemi Awolowo University, Ile-Ife.

Ajibade, Mobolaji Oyebisi. 2014. 'The Role of Pentecostal Churches in Curbing Social Ills in Ife Central Local Government, Osun State.' Journal of National Association of Women in Colleges of Education (JOWICE) 18: 238-241.

Ajibade, Mobolaji Oyebisi. 2016. 'Filmic Construction of Pentecostal's Roles in Sustainable Democracy.' Journal of Nigeria Association for the Study of Religions 25, no. 2: 233-245.

Ayegboyin, Deji, and S. Ademola Ishola, eds. 1997. African Indigenous Churches: An Historical Perspective. Lagos: Greater Heights Publication.

Ayuk, Ausaji Ayuk. 2002. 'The Pentecostal Transformation of Nigerian Church Life.' Asian Journal of Pentecostal Studies 5, no. 2: 189-204.

Benjamin, C. D. Diara, and G. Onah Nkechinyere. 2014. 'The Phenomenal Growth of Pentecostalism in Contemporary Nigerian Society: A Challenge to Mainline Churches.' Mediterranean Journal of Social Sciences 5, no. 6: 395-402.

Corten, Andrew, and Ruth Marshall-Fratani, eds. 2001. Between Babel and Pentecost Transnational Pentecostalism in Africa and Latin America. Indiana University Press.

Gaiya, Musa A. B. 2015. 'Charismatic and Pentecostal orientations in Nigeria.' Nova Religio: The Journal of Alternative and Emergent Religions 18, no. 3: 63-79.

Hastings, Adrian. 1976. African Christianity. London: Geoffrey Chapman.

Lindhardt, Martin. 2010. 'Charismatic/Pentecostal Appropriation of Media Technologies in Nigeria and Ghana.' Journal of Religion in Africa, 28, no 3: 258-277.

McCain, Danny. 2013. 'The Metamorphosis of Nigerian Pentecostalism. From Signs and Wonders in the Church to Service and Influence in Society.' In Spirit and Power: The Growth and Global Impact of Pentecostalism, edited by Donald E. Miller, Kimont H. Sargeant, and Richard Flory, 160-184. New York: Oxford University Press.

Magbadelo, John Olusola. 2004. 'Pentecostalism in Nigeria: Exploiting or Edifying the Masses?' African Sociological Review/Revue Africaine de Sociologie 8, no. 2: 15-29. 
Maxwell, David. 2006. African Gifts of the Spirit: Pentecostalism and the Rise of a Zimbabwean Transnational Religious Movement. Oxford: James Currey.

Miller, Donald E., and Tetsunao Yamamori. 2007. Global Pentecostalism: The New Face of Christian Social Engagement. Berkeley: University of California Press.

NCEF (National Christian Elders Forum). 2018. 'The Imperative of Christian Participation in Governance.' 19 June 2018. www.proshareng.com/news/POLITICS/TheImperative-of-Christian-Participation-in-Governance-/40420.

Ojo, Mathews A. 1995. 'The Charismatic Movement in Nigeria Today.' International Bulletin of Missionary Research 19, no. 3: 114-118.

Olokor, Friday. 2018. 'Restructuring Should Dominate 2019 Polls - Christian Elders, Others.' 4 September 2018. https://punchng.com/restructuring-should-dominate-2019polls-christian-elders-others/.

Omotoye, Rotimi Williams. 2010. 'A Critical Examination of the Activities of Pentecostal Churches in National Development in Nigeria.' CESNUR: Centro Studi sulle Nuove Religioni. www.cesnur.org/2010/omotoye.htm.

Togarasei, Lovemore. 2015. 'Modern/Charismatic Pentecostalism as a form of Religious Secularisation in Africa.' Studia Historiae Ecclessiastica 41, no. 1: 56-66.

Uchegbue, Christian Onyenaucheya. 2013. 'The Place of the Church in the SocioPolitical and Economic Liberation of Nigeria.' Proceedings of the 1st Annual International Interdisciplinary Conference (AIIC) : 141-154. Azores, Portugal.

Ukah, Asonzeh. 2006. 'Branding God: Advertising and the Pentecostal industry in Nigeria.' Liwuram: Journal of Humanities 13: 83-106. 